\title{
A study on relationship between capital employed efficiency and operational cash flow: Evidence from Tehran Stock Exchange
}

\author{
Mohammad Hassani $^{\mathbf{a}^{*}}$ and Mehri Misaghi ${ }^{\mathrm{b}}$
}

${ }^{a}$ Head of Accounting Department, Tehran North Branch, Islamic Azad University, Tehran, Iran

${ }^{b}$ Master of Accounting, Tehran North Branch, Islamic Azad University, Tehran, Iran

C H R O N I C L E

Article history:

Received December 2, 2012

Received in revised format

18 March 2013

Accepted 19 March 2013

Available online

March 202013

Keywords:

Capital Employed Efficiency

Operational Cash Flow

Growth Opportunity

Profitability

\section{A B S T R A C T}

Capital employed efficiency is one of the intellectual capital components based on value added intellectual capital model. It is calculated by dividing value added on capital employed. Operational cash flow is made from operating activities. It is expected that created value added from capital employed could make more operational cash flow. This paper investigates the relationship between capital employed efficiency and operating cash flow. To test this hypothesis, data has been collected from a sample of 161 firms in Tehran Stock Exchange over the period 2008-2012. Results show that there is a positive and significant relationship between capital employed efficiency and operational cash flow. In other words, more cash flow from operational is created through increasing the amount of value added based on capital employed.

\section{Introduction}

Operating cash flow plays an important role on measuring the performance of different business units, it is the third primary financial statement in a corporate financial report, and there are literally many studies on learning the effects of the behavior of cash flow. Nurnberg (2006), for instance, studied the distorting effects of acquisitions and dispositions on net operating cash flow. Dechow et al. (1998) proposed a model of earnings, cash flows and accruals by assuming a random walk sales process, variable and fixed costs, and that the only accruals were accounts receivable and payable, and inventory. Francis and Eason (2012) investigated the relationship between accruals and the naïve out-of-sample prediction of operating cash flow.

Corresponding author. Tel: +989193007050

E-mail: m_hassani@iau-tnb.ac.ir (M. Hassani)

(c) 2013 Growing Science Ltd. All rights reserved. doi: 10.5267/j.msl.2013.03.019 
Edmonds et al. (2011) investigated the effect of meeting or beating analysts' operating cash flow forecasts on a firm's cost of debt. They studied the relative importance and effect of meeting or beating analysts' operating cash flow forecasts on a firm's cost of debt. Their results indicated that firms meeting/beating analysts' cash flow forecasts had higher initial bond ratings as well as lower initial bond yields. Luo (2008) collected individual cash flows from unusual operations and examined their characteristics for forecasting future cash flows. The results indicated that the unusual individual cash flow items contain a substantial incremental predictive capability for future cash flows. Additional return results demonstrated that stock prices fail to reflect their predictive value, recommending that the current reporting practice could mislead investor perceptions of a firm's cash generating capability and investors could take advantage of a more explicit presentation of cash flows from operations. There are different methods for calculating operating cash flow and Farshadfar and Monem (2013) provided some evidences on the advantage of direct method cash flow components for forecasting future cash flows.

Francis (2011) investigated out-of-sample cash flow prediction and cash distributions to shareholders. They provided empirical evidence that net cash distributions to shareholders could provide a noteworthy context for improving the out-of-sample prediction of cash flow suggesting that net distributions to shareholders could be an indicator for future cash flow, and the current study hypothesized that the accuracy of out-of-sample forecasts could increase with the magnitude of the shareholder distributions.

Akbar et al. (2011) investigated the value relevance of cash flows, current accruals, and non-current accruals in the UK. They reported that requiring a cash flow statement, as opposed to a funds flow statement, could improve the information content of financial statements in the UK. McInnis and Collins (2011) investigated the impact of cash flow forecasts on accrual quality and benchmark beating. They reported that firms switch to other benchmark-beating mechanisms, such as real activities manipulation and earnings guidance in response to the provision of cash flow forecasts. Dimitropoulos et al. (2010) investigated the informational quality of annual accounting earnings within Greek banking institutions and reported that earnings had higher incremental importance in explaining stock return movements compared to cash flows since earnings change were found to affect stock returns positively.

In this paper, we investigate the effects of various factors on operational cash flow in Tehran Stock Exchange listed companies. The organization of this paper first presents details of the proposed study in section 2 while section 3 demonstrates the results of our survey and concluding remarks are given in the last to summarize the contribution of the paper.

\section{The proposed study}

The proposed study of this paper gathers the information of some selected firms listed in Tehran Stock Exchange (TSE). In our selection policy, we decided to select only firms whose financial fiscal year ended March. In addition, no holding firm was permitted to our investigation and they should not have changed their fiscal year during the years of study, 2008-2012. We also excluded the information of banks, financial institutions, etc. The main hypothesis of the survey is as follows,

Main hypothesis: There is a meaningful relationship between capital employed efficiency and operating cash flow.

There are also two sub hypotheses associated with the proposed study, which are as follows,

1. There is a difference between firms with high level of capital employed efficiency and firms with low level of capital employed efficiency in terms of operating cash flow. 
2. There is a difference between firms with high level of operating cash flow and firms with low level of operating cash flow in terms of capital employed efficiency.

The proposed study of this paper considered the following regression model,

Operational Cash Flow $w_{i, t}=\beta_{0}+\beta_{1}$ Capital Employed Efficiency ${ }_{i, t}+\beta_{2}$ Size $_{i, t}$

$$
+\beta_{3} \text { Leverage }_{i, t}+\beta_{4} \text { Growth Opportunity }_{i, t}+\beta_{5} \text { Profitability }_{i, t}+\varepsilon_{i, t},
$$

where operating cash flow is the dependent variable and it is considered as a linear function of capital employed efficiency, size of firm, firms' leverage, growth opportunity and profitability. Fig. 1 shows details of our proposed study,

\begin{tabular}{|c|c|c|}
\hline \multicolumn{2}{|c|}{ Operational Cash Flow } & \multicolumn{2}{c|}{ Capital employed efficiency } \\
\hline Size & Growth opportunity & Profitability \\
\hline
\end{tabular}

Fig. 1. The proposed study

As we can observe from Fig. 1, there are four control variables and one main variable associated with the proposed study of this paper. In this paper, we homogenize operational cash flow through dividing it by total assets. Capital employed efficiency is also calculated from a ratio of value added divided by total acquired equities or total assets minus intangible assets. In this paper, value added is calculated by summing up total depreciation, paid salaries, paid interest, dividend, total paid tax and accumulated earnings. In addition, sizes of firms are calculated by taking the natural logarithm of total assets and leverage is computed as ratio of book value of total liabilities on total assets. Growth opportunity is calculated as a ratio of market value of total equities on book value of total equities and finally, profitability is calculated as a ratio of net profit divided by total equities. Table 1 shows some of the basic statistics.

Table 1

Some basic statistics

\begin{tabular}{lcccccc}
\hline & Symbol & $\begin{array}{c}\text { Mean } \\
\text { Statistic }\end{array}$ & $\begin{array}{c}\text { Median } \\
\text { Statistic }\end{array}$ & $\begin{array}{c}\text { Std. Dev. } \\
\text { Statistic }\end{array}$ & Skewness & Kurtosis \\
\hline Operational cash flow & OCF & 0.098699 & 0.088715 & 0.123949 & 0.485912 & 5.940070 \\
Capital employed efficiency & CEE & 0.185961 & 0.211434 & 0.300479 & -2.776434 & 20.20182 \\
Size & Size & 5.714633 & 5.658395 & 0.612100 & 0.906351 & 4.281317 \\
Leverage & Lev & 0.708559 & 0.671365 & 0.280605 & 2.550525 & 16.95053 \\
Growth opportunity & GO & 1.076735 & 1.134077 & 11.81552 & -1.924054 & 110.5576 \\
Return on equity & ROE & 0.211104 & 0.230998 & 0.694841 & -2.658806 & 29.57680 \\
\hline
\end{tabular}

As we can observe from the results of Table 1, operating cash flow is about $9.9 \%$ of total assets and the average capital employed efficiency is about $18.6 \%$. The preliminary results do not indicate that the data are normally distributed. In order to examine whether the data are stationary, Dickey Fuller unit root test has been used and since all Chi-Square values are statistically significance, we can accept that the data are stationary. Table 2 summarizes the results of our survey.

Table 2

The results of Dickey Fuller test

\begin{tabular}{lccc}
\hline & Symbol & Chi-Square & P-value \\
\hline Operational cash flow & OCF & 590.765 & 0.0000 \\
Capital employed efficiency & CEE & 391.016 & 0.0051 \\
Size & Size & 560.626 & 0.0000 \\
Leverage & Lev & 382.814 & 0.0111 \\
Growth opportunity & GO & 340.485 & 0.0010 \\
Return on Equity & ROE & 537.038 & 0.0000 \\
\hline
\end{tabular}


One of other important issues when we intend to use linear regression technique is to consider the relationship between independent variables. Table 3 demonstrates the results of Pearson correlation ratios among various independent variables.

Table 3

The results of Pearson correlation ratios

\begin{tabular}{|c|c|c|c|c|c|c|}
\hline Symbol & OCF & CEE & Size & Lev & GO & ROE \\
\hline OCF & 1.00 & & & & & \\
\hline P-value & - & & & & & \\
\hline CEE & 0.289221 & 1.00 & & & & \\
\hline P-value & 0.000 & - & & & & \\
\hline Size & 0.042361 & 0.176947 & 1.00 & & & \\
\hline P-value & 0.2511 & 0.000 & - & & & \\
\hline Lev & -0.198878 & -0.873959 & -0.051142 & 1.00 & & \\
\hline $\mathrm{P}$-value & 0.000 & 0.000 & 0.1657 & - & & \\
\hline GO & 0.010156 & 0.178081 & 0.045394 & -0.144236 & 1.00 & \\
\hline P-value & 0.7883 & 0.000 & 0.2187 & 0.0001 & - & \\
\hline ROE & 0.092841 & 0.144567 & 0.079851 & -0.053653 & 0.167177 & 1.00 \\
\hline $\mathrm{P}$-value & 0.0117 & 0.0001 & 0.0303 & 0.1459 & 0.000 & - \\
\hline
\end{tabular}

As we can observe from the results of Table 3, there are not strong correlations among pairs of independent variables except one case between Lev and CEE and during the analysis; we need to consider this issue, very carefully. In addition, we need to whether to choose fixed or random effect and the results of our investigation indicate that we could apply fixed effect technique.

\section{The results}

In this section, we present details of our findings on applying ordinary least square technique on testing various hypotheses of this survey.

\subsection{The first hypothesis}

The first hypothesis of this paper studies the relationship between operational cash flow and capital employed efficiency. Table 4 shows details of regression model as follows,

\section{Table 4}

The results of regression analysis

\begin{tabular}{lccccc}
\hline & Symbol & Coefficient & Std. Error & t-student & P-value \\
\hline Intercept & & 2.024257 & 0.304570 & 6.646289 & 0.0000 \\
Capital employed efficiency & CEE & 0.064226 & 0.031806 & 2.019332 & 0.0439 \\
Size & Size & -0.337439 & 0.053240 & -6.338101 & 0.0000 \\
Growth opportunity & GO & -0.000430 & 0.000407 & -1.057937 & 0.2905 \\
Return on equity & ROE & 0.001977 & 0.005991 & 0.330041 & 0.7415 \\
\hline
\end{tabular}

The results of $F$ value for the regression analysis is equal to 2.3145 with P-value $=0.0000$, which means there is a linear relationship between independent variable and dependent variable. DurbinWatson ratio is equal to 2.3154, which means there is no autocorrelation between residuals. The first hypothesis of this survey studies the relationship between operating cash flow and capital employed efficiency and we see a positive relationship between these two variables when the level of significance is five percent. Therefore, we can confirm the first hypothesis of this survey.

\subsection{The second hypothesis}

The second hypothesis of this paper considers whether there is a difference between firms with high level of capital employed efficiency and firms with low level of capital employed efficiency in terms 
of operational cash flow or not. To examine this hypothesis, we divide firms into five groups in terms of their capital employed efficiency and compared group one with group five statistically to see whether the mean of these two groups are equal or not. The results of t-student for comparing means of the first and fifth groups is equal to -0.240783 with $\mathrm{p}$-value $=0.8098$. Therefore, we cannot confirm this hypothesis since the statistical observation is not significant.

\subsection{The third hypothesis}

The third hypothesis of this paper considers whether there is a difference between firms with high level of operational cash flow and firms with low level of operational cash flow efficiency in terms of capital employed efficiency or not. To examine this hypothesis, again, we have divided firms into five groups in terms of their operational cash flow and compared group one with group five statistically to see whether the mean of these two groups are equal or not. The results of t-student for comparing means of the first and fifth groups is equal to 2.048195 with $\mathrm{p}$-value $=0.0409$. As we can observe, the result is statistically significant and we can conclude that there is, indeed, a difference between firms with high level of operational cash flow and firms with low level of operational cash flow in terms of capital employed efficiency.

\section{Conclusion}

In this paper, we have presented an empirical investigation to study the impact of capital employed efficiency on operational cash flow through four control variables; namely size of firm, growth opportunity, leverage and profitability. The study has performed in Tehran Stock Exchange and the results have confirmed that there was a meaningful relationship between capital employed efficiency and operating cash flow. In addition, there was no difference between firms with high level of capital employed efficiency and firms with low level of capital employed efficiency in terms of operational cash flow. Finally, there was a difference between firms with high level of operational cash flow and firms with low level of operational cash flow in terms of capital employed efficiency.

\section{Acknowledgment}

The authors are grateful to constructive comments on earlier version of this work, which has significantly contributed on the quality of the accomplished research.

\section{References}

Akbar, S., Ali Shah, S.Z., \& Stark, A.W. (2011). The value relevance of cash flows, current accruals, and non-current accruals in the UK. International Review of Financial Analysis, 20(5), 311-319.

Dechow, P.M., Kothari, S.P., \& Watts, R.L. (1998). The relation between earnings and cash flows. Journal of Accounting and Economics, 25(2), 133-168.

Dimitropoulos, P.E., Asteriou, D., \& Koumanakos, E. (2010). The relevance of earnings and cash flows in a heavily regulated industry: Evidence from the Greek banking sector. Advances in Accounting, 26(2), 290-303

Edmonds, C.T., Edmonds, J.E., \& Maher, J.J. (2011). The impact of meeting or beating analysts' operating cash flow forecasts on a firm's cost of debt. Advances in Accounting, 27(2), 242-255.

Farshadfar, S., \& Monem, R. (2013). Further evidence on the usefulness of direct method cash flow components for forecasting future cash flows. The International Journal of Accounting, 48(1), 111-133.

Francis, R.N. (2011). Out-of-sample cash flow prediction and cash distributions to shareholders. Advances in Accounting, 27(1), 1-9.

Francis, R.N., \& Eason, P. (2012). Accruals and the naïve out-of-sample prediction of operating cash flow. Advances in Accounting, 28(2), 226-234.

Luo, M. (2008). Unusual operating cash flows and stock returns. Journal of Accounting and Public Policy, 27(5), 420-429. 
1094

McInnis, J., \& Collins, D.W. (2011). The effect of cash flow forecasts on accrual quality and benchmark beating. Journal of Accounting and Economics, 51(3), 219-239.

Nurnberg, H. (2006).The distorting effects of acquisitions and dispositions on net operating cash flow. Accounting Forum, 30(3), 209-226. 